\title{
CORRECTION
}

\section{Correction: Clinical utility of genetic testing in 201 preschool children with inherited eye disorders}

Eva Lenassi, PhD, FEBO, Jill Clayton-Smith, MD, FRCP, Sofia Douzgou, PhD, FRCP, Simon C. Ramsden, PhD, FRCPath, Stuart Ingram, MSC, Georgina Hall, MSc, Claire L. Hardcastle, BSc, Tracy A. Fletcher, BSc, Rachel L. Taylor, PhD, Jamie M. Ellingford, PhD, William D. Newman, FRCOphth, Cecilia Fenerty, FRCOphth, Vinod Sharma, FRCOphth, I. Chris Lloyd, FRCOphth, Susmito Biswas, FRCOphth, Jane L. Ashworth, PhD, FRCOphth, Graeme C. Black, DPhil, FRCOphth and Panagiotis I. Sergouniotis, PhD, FRCOphth

Genetics in Medicine (2021) 23:2023; https://doi.org/10.1038/s41436-020-01068-8

Correction to: Genetics in Medicine 22, 745-751 (2020); https://doi. org/10.1038/s41436-019-0722-8; published online 18 December 2019

This Article was originally published under an Open Access [CC BY-NC-ND 4.0] licence, but has now been made available under a [CC BY 4.0] license. The PDF and HTML versions of the Article have been modified accordingly.

Open Access This article is licensed under a Creative Commons Attribution 4.0 International License, which permits use, sharing, adaptation, distribution and reproduction in any medium or format, as long as you give appropriate credit to the original author(s) and the source, provide a link to the Creative Commons license, and indicate if changes were made. The images or other third party material in this article are included in the article's Creative Commons license, unless indicated otherwise in a credit line to the material. If material is not included in the article's Creative Commons license and your intended use is not permitted by statutory regulation or exceeds the permitted use, you will need to obtain permission directly from the copyright holder. To view a copy of this license, visit http://creativecommons. org/licenses/by/4.0/.

(c) The Author(s) 2020 